\title{
SOIL SEED BANK IN SEASONAL SEMIDECIDUOUS FOREST AND ABANDONED PASTURE
}

\author{
Sustanis Horn Kunz ${ }^{2 *}$ and Sebastião Venâncio Martins ${ }^{3}$
}

\footnotetext{
${ }^{1}$ Received on 04.02.2014 accepted for publication on 24.10.2016.

${ }^{2}$ Universidade Federal do Espírito Santo, Departamento deCiências Florestais e da Madeira,Alegre,ES- Brasil.E-mail:<sustanis@gmail.com>.

${ }^{3}$ Universidade Federal de Viçosa, Departamento de Engenharia Florestal, Viçosa- MG, Brasil. E-mail: <venancioufv@gmail.com>.

*Corresponding author.
}

\begin{abstract}
The objective of this study was to characterize the seed bank in the soil of different successional stages of Seasonal Semideciduous Forest and abandoned pasture in order to understand the natural regeneration potential of these areas. At each successional stage, 30 samples of soil were collected in the rainy and dry seasons to evaluate the qualitative heterogeneity of the forest, at the regeneration stage (FEA) forest, intermediate regeneration stage forest (ISF) and pasture (PAS). The species were classified according to the life form, successional group and dispersion syndrome. The number of individuals germinated was significantly higher $(\mathrm{p}<0.001)$ in the ISF and in the rainy season (15,949 individuals). Richness was higher in the pasture area ( 79 species), with a significant difference only between the environments. Most species are herbaceous (49.5\%), pioneers (76.5\%) and zoocory was the main dispersion syndrome (49\% of species). The results show that seed bank in the fragment of the regeneration advanced stage forest presents the highest resilience potential, since it is formed by different life forms and, mainly, by early and late secondary species.
\end{abstract}

Key words: Forest succession; Natural regeneration; Seed density.

\section{BANCO DE SEMENTES DO SOLO DE FLORESTA ESTACIONAL SEMIDECIDUAL E DE PASTAGEM ABANDONADA}

\begin{abstract}
RESUMO - O presente estudo teve como objetivo caracterizar o banco de sementes no solo de diferentes estádios sucessionais de Floresta Estacional Semidecidual e de pastagem abandonada, a fim de compreender o potencial de regeneração natural destas áreas. Em cada estádio sucessional, denominados de floresta em estádio avançado de regeneração (FEA), floresta em estádio médio de regeneração (FEM) e pastagem (PAS), foram coletadas 30 amostras de solo na estação chuvosa e seca, para avaliar a heterogeneidade quali-quantitativa sazonal. As espécies foram classificadas quanto à forma de vida, grupo sucessional e síndrome de dispersão. O número de indivíduos germinados foi significativamente maior ( $p<0,001)$ na FEM e na estação chuvosa (15.949 ind.). Já a riqueza foi maior na área de pastagem (79 espécies), havendo diferença significativa apenas entre os ambientes. A maioria das espécies é herbácea $(49,5 \%)$, pioneiras $(76,5 \%)$ e a zoocoria foi a principal síndrome de dispersão (49\% das espécies). Os resultados mostram que o banco de sementes do trecho de floresta em estádio avançado de regeneração possui maior potencial de resiliência, pois éformado por diferentes formas de vida e, principalmente, por espécies secundárias iniciais e tardias.
\end{abstract}

Palavras-chave: Densidade de sementes; Regeneração natural; Sucessão florestal. 


\section{INTRODUCTION}

Seed bank in the soil corresponds to the stock of viable seeds that remain in the soil surface or in the deepest layers at a particular time and place (WALCK et al., 2005) and may play an important role in the secondary succession. Seed density in the soil decreases significantly as it approaches the final stage of succession; however, studies on seed bank do not always contemplate areas with different successional stages in the same fragment. Araújo et al. (2001), for example, when analyzing the seed bank of a successional forest fragment at different ages $(6,17$ and 30 years old) in the Eastern Amazon, recorded higher densities in the 6-year old forest $\left(2,848 \mathrm{seeds} / \mathrm{m}^{2}\right)$, with greater prevalence of pioneer trees. Lindner (2009) studied the structure of the soil seed bank in Ombrophylous Dense Forest in Rio de Janeiro with different disturbance records and found higher species richness and floristic diversity in altered stretches than in not-disturbed forest fragments.

In seasonal semideciduous forests in the Atlantic Forest, there are few studies on seed bank in the soil of areas at different successional stages inserted in the same forest matrix, whose information allows knowing the resilience of the landscape towards a disturbance. In the state of São Paulo, the studies of Baider et al. (2001) and Martins and Engel (2007) stood out. In the semideciduous forests in the State of Minas Gerais, studies on seed banks were carried out in pasture, eucalyptus and forest areas (COSTALONGA et al., 2006); in secondary forest in two different topographic sites (BATISTA NETO et al., 2007) and in two areas of secondary forest (SOUZA et al., 2006).

Estação de Pesquisa Treinamento e Educação Ambiental Mata do Paraíso (Mata do Paraíso Environmental Training and Education Research Station) is part of one of the largest fragments of native forest in Zona da Mata region in Minas Gerais and is an environmental matrix at different successional stages (primary forest, secondary forests and abandoned pasture) of which little is known about the composition of the seed bank. Because it is a typical landscape of the region and probably in southeastern Brazil, the objective of this study is to answer the following questions: does the seed bank of the same forest fragment present seasonal variations in terms of floristic composition and abundance? Is the seed bank of a primary forest provided with greater potential for resilience, even though it is embedded in a mosaic of secondary forests and pasture? Does the abandoned pasture in the process of regeneration, which is surrounded by forest, present a seed bank with pioneer tree species?

In this sense, the objective of this study is to characterize the soil seed bank in the rainy and dry seasons of areas at different successional stages (secondary forest) and abandoned pasture area, in order to understand the natural regeneration potential of these areas.

\section{MATERIALAND METHODS}

\subsection{Study area}

The study was carried out at the Estação de Pesquisa e Treinamento em Educação Ambiental Mata do Paraíso (Environmental Education Research and Training Station Mata do Paraíso) - EPTEA in Mata do Paraíso (2048'07" $\mathrm{S}$ and $\left.42^{\circ} 51^{\prime} 31^{\prime \prime} \mathrm{W}\right)$, located in the municipality of Viçosa, state of Minas Gerais. EPTEA has 195 ha of area and altitude ranging from 690 to $800 \mathrm{~m}$. The climate in the region is Cw type (KÖPPEN, 1948), with annual average temperature of $21.8^{\circ} \mathrm{C}$ and annual rainfall of $1,314.2$ $\mathrm{mm}$ (CASTRO et al., 1983). The vegetation of the reserve is termed Semidecidual Seasonal Forest, domain of Atlantic Forest (IBGE, 2012) and the relief is composed of wavy to heavily undulating type. The predominant soils are Red-Yellow Latosol and Red-Yellow Podzolic (BARUQUI et al., 1983).

Fragments of forest and pasture chosen for collecting the seed bank in the soil are under the same relief conditions (flat to slightly wavy) and soil (Red-Yellow Latosol), but they present different records of disturbance and regeneration. The section termed in this study as forest in the intermediate regeneration stage (IRS), according to the CONAMA resolution no. 392 of 2007 , has been in the process of regeneration since 1963, that is, 47 years ago until the realization of the present study. The other section, termed as advanced stage of regeneration (AER), according to resolution of CONAMA, has been selectively exploited for wood and has been free from anthropic disturbances in the last four decades. A third area is characterized by abandoned pasture (APS) of Molsasses grass (Melinis minutiflora P. Beauv.) and is configured as a large anthropic clearing within EPTA forest matrix. 


\subsection{Soil seed bank sampling and germination}

Ten plots of $5 \mathrm{~m} \times 10 \mathrm{~m}$, with a distance of $10 \mathrm{~m}$ between subsequent plots were demarcated in each fragment for the study of the natural regeneration. Seed banks were randomly collected in each plot, totaling 10 samples.

The soil sample, excluding litter, was removed with the aid of a metal rectangle $(25 \mathrm{~cm} \times 39 \mathrm{~cm} \times 5 \mathrm{~cm})$ and wrapped in plastic trays, totaling $2.92 \mathrm{~m}^{2}$ of soil of each stretch. Each sample was composed of three subsamples, which were collected at different points in the plots to maximize species sampling. According to Butler and Chazdon (1998), due to the spatial distribution of the species, a larger number of samples and better distributed around the area allows greater precision in the species sampling. Collections were carried out in the rainy (December/2008) and dry (July/ 2009) seasons, in order to evaluate the qualitative and quantitative heterogeneity of the seed bank in the two seasons.

The trays containing the seed bank were kept in the forest nursery of the Federal University of Viçosa (UFV), in a greenhouse under shade-type screen (65\% shade), with daily automatic spraying. Trays with sterilized coarse sand were added to verify a likely contamination by external diaspores. Trays were periodically rotated to ensure that all trays were submitted to the same environmental conditions.

The seedling emergence method (BROWN, 1992) was used to estimate the abundance and richness of herbaceous, shrub and tree species present in the bank. The individuals of lianas and grasses were only quantified. The evaluations were done fortnightly for four months. After this period, the soil samples were revolved to ensure greater number of viable seed germination and quantification continued for another two months. The herbaceous, shrub and arboreal individuals that emerged from the seed bank were identified with the aid of specialized bibliography, consults with experts VIC herbarium of the Federal University of Viçosa. Those unidentified remained in the trays until they developed to the point of recognition. The scientific names and their authors were updated with the Missouri Botanical Garden (http://www.tropicos.org/) and the Angiosperm Phylogeny Group - APG III (APG 2009) system was adopted. The species were classified as life form (tree, shrub and herbaceous), dispersion syndrome (zoochory, anemochory and autochory) and successional group (pioneer, secondary and late secondary), following the works of Baider et al. (1999), Costalonga et al. (2006), Batista Neto et al. (2007) and Camargos et al. (2013).

\subsection{Data analysis}

Data of species richness and seed abundance were submitted to analysis of variance (ANOVA), to test the differences between the successional stages and the seasonality of the environment. To attend ANOVA prepositions, the variables responses (richness and abundance) were submitted to the homogeneity of variance test (Levene' test). Thus, seed abundance data among the fragments and at the stations were transformed by $\log (X+1)$, to again proceed with the homogeneity test. Subsequently, the Tukey test at 5\% was used to identify the significant differences between the groups. In order to test the difference in species composition between areas, the Bi-factorial Similarity Analysis (ANOSIN) was carried out in the R program (R DEVELOPMENT CORE TEAM,).

\section{RESULTS}

The total number of germinated seeds, considering each fragment, was 3,471 in the forest at an advanced stage of regeneration $\left(1,188\right.$ seeds $\left./ \mathrm{m}^{2}\right), 20,704$ in the intermediate stage forest $\left(7,089 \mathrm{seeds} / \mathrm{m}^{2}\right)$ and 11,302 in the pasture $\left(3,869 \mathrm{seeds} / \mathrm{m}^{2}\right)$, presenting a significant difference between ASF and ISF $(p<0.001)$ and ASF and PAS $(p<0.001)$ environments. No difference $(p>$ 0.05 ) was found among pasture and forest in the average stage.

Significant variations were found in the seed stock according to the seasons of the year $\left(\mathrm{F}_{1,54}=269.38\right.$; $\mathrm{p}<0.001$ ), in which the bank collected in the rainy season showed the highest amount of germinated seeds in all the fragments (Table 1), but no interaction was found between seasonality and the environment $\left(F_{2,44}=0.56\right.$; $\mathrm{p}>0.05)$. The fragment of the intermediate stage forest showed on average of 861 germinated seeds more than ASF (Tukey p $<0.001$ ) and 473 seeds more than SBP (Tukey $\mathrm{p}>0.001$ ). Yet, pasture presented on average of 388 seeds germinated more than ASF (Tukey p $<0.001$ ). Considering the seasonality, there more 655 germinated seeds in the rainy season than in the dry season (Tukey $\mathrm{p}<0.001)$.

Revista Árvore, Viçosa-MG, v.40, n.6, p.991-1001, 2016

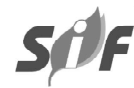


Table 1 - Density (seeds $/ \mathrm{m}^{2}$ ) and number of seeds (NS) of the soil seed bank from forest and pasture sections in wet and dry seasons.

Tabela 1 - Densidade (sem. $/ \mathrm{m}^{2}$ ) e número de sementes (NS) do banco de sementes no solo dos trechos de floresta e de pastagem nas estações chuvosa e seca.

\begin{tabular}{|c|c|c|c|c|}
\hline & \multicolumn{2}{|c|}{ Estação Chuvosa } & \multicolumn{2}{|c|}{ Estação Seca } \\
\hline & NS & sem. $/ \mathrm{m}^{2}$ & NS & sem. $/ \mathrm{m}^{2}$ \\
\hline FEA & 2.539 & 869 & 932 & 319 \\
\hline FEM & 15.949 & 5.461 & 4.755 & 1.628 \\
\hline PAS & 8.935 & 3.059 & 2.367 & 810 \\
\hline
\end{tabular}

In the three sections, 111 taxa were identified, 89 at the species level, nine at the genus level, one at the family level and twelve remained indeterminate. In addition to these, the group of grasses and vines were found, totaling 113 plant morphospecies present in the seed bank in the soil. Table 2 shows the families, genera and species identified from the seed bank in the soil.

Fragment of the pasture was the one with the highest richness ( 79 species), followed by the intermediate stage forest (74) and the forest in an advanced stage of regeneration with 71 species (Table 3 ), with significant variations of richness between the stretches. The type of environment (ASF, ISF and PAS) promoted significant variation on the average species richness per plot $\left(F_{(2,57)}=8.578, p<0.001\right)$. Fragments of the intermediate stage forest presented an average of 5.2 more species than PAS (Tukey, $\mathrm{p}=0.032$ ) and 8.4 more species than ASF (Tukey $\mathrm{p}<0.001$ ). Among the AFS and PAS physiognomies, the variation of the species richness observed was not significant (Tukey, $p=0.296$ ), as seasonality did not significantly interfere in the soil seed bank richness $\left(F_{(1,54)}=2,344\right)$. However, the composition of species is different between the fragments (ANOSIM, $p=0.001$ ), probably a reflection of the successional stage that each area is found.

Considering all the fragments, the most important ecological group was the pioneers $(76.5 \%$ of the total of species), among which the herbaceous had great prominence ( 44 species). This form of life predominated in all fragments, corresponding to $49.5 \%$ of the total species and $41.8 \%$ of the total number of individuals.

Early and late secondary were not very representative, contributing with only four and one tree species, respectively. In the three fragments, a predominance of pioneer tree-shrub species (ASF 31 ; ISF - 37; PAS - 28 species) was found as well as initial secondary (PAS - 1 species; ISF - 3; ASF - 4), while late species were sampled only in the forest at an advanced stage of regeneration (1 species).

In relation to dispersion syndrome, the species are mainly zoocoric (49\%) and anemocoric (36\%), with little representation of autochromatic species (Table 2).

\section{DISCUSSION}

The variability in the density of seeds stored in the bank in the forest soil may be related specially to soil depth (BAIDER et al., 1999; LUZURIAGA et al., 2005), successional stage (LINDNER, 2009) and seasonality (GROMBONE-GUARATINI; RODRIGUES, 2002). In this study, a great variation was found in the seed density ( $319 \mathrm{seed} / \mathrm{m} 2$ to $5,461 \mathrm{seed} / \mathrm{m} 2$ ), in which the fragment in the intermediate regeneration stage forest stood out (Table 1).

Secondary forests in the process of regeneration, as is the case of the intermediate stage forest and pasture, are basically composed of shrub-tree species with efficient seed reproduction mechanisms and their longevity (HORN, 1974), which promotes a large stock of seeds in the soil. Thus, seed density decreases significantly as succession advances, where areas of mature forest may have a density of 31.6 to 872 seeds $/ \mathrm{m}^{2}$ (GROMBONEGUARATINI; RODRIGUES, 2002; BAIDER et al., 2001 ), while in areas of secondary forest at ages ranging from three to six years old, densities of $2,847 \mathrm{seeds} / \mathrm{m}^{2}$ (ARAÚJO et al., 2001) to $11,028 \mathrm{seeds} / \mathrm{m}^{2}$ (BAIDER et al., 2001) had already been recorded.

In other areas of secondary forest in the region of Zona da Mata, state of Minas Gerais, densities of $949 \mathrm{seeds} / \mathrm{m}^{2}$ (BATISTA NETO et al., 2007) to 1,346 seeds $/ \mathrm{m}^{2}$ (SOUZA et al., 2006) were recorded. In the present study, the lowest values of density on pasture, when compared to the intermediate stage forest, may be due to the difficulty of the seed to reach the soil because of the dense biomass layer of the Melinis minutiflora grass. 
Table 2 - Listing of sampled species in the soil seed bank from forest sections in different successional stages and from abandoned pasture and characterization according to life form (FV), environmental group (GE) and dispersion syndrome $(\mathrm{SD})$. Arbo.= arboreal, $\mathrm{Arbu} .=$ shrub; Herb. $=$ herbaceous; $\mathrm{Pi}=$ pioneer; $\mathrm{Si}=$ early secondary; $\mathrm{St}=1$ late secondary; Zooc.= zoochory; Anem. $=$ anemochory; Aut.= autochory; SC $=$ no characterization.

Tabela 2 - Listagem das espécies amostradas no banco de sementes no solo dos trechos de floresta em diferentes estádios sucessionais e de pastagem abandonada e caracterização quanto a forma de vida (FV), grupo ecológico (GE) e sindrome de dispersão (SD). Arbo. = arbórea, Arbu. = arbusto; Herb. $=$ herbácea; $P i=$ pioneira; $S i=$ secundária inicial; $S t=$ secundária tardia; Zooc. = zoocoria; Anem. = anemocoria; Aut. = autocoria; $S C=$ sem caracterização.

\begin{tabular}{|c|c|c|c|c|}
\hline Famílias & Espécies & FV & GE & SD \\
\hline AMARANTHACEAE & Amaranthus deflexus $\mathrm{L}$. & Herb. & $\mathrm{Pi}$ & Zooc. \\
\hline ARECACEAE & Euterpe edulis Mart. & Arbo. & $\mathrm{St}$ & Zooc. \\
\hline APOCYNACEAE & Asclepias curassavica $\mathrm{L}$. & Herb. & $\mathrm{Pi}$ & Anem. \\
\hline \multirow[t]{24}{*}{ ASTERACEAE } & Ageratum conyzoides L. & Herb. & $\mathrm{Pi}$ & Zooc. \\
\hline & Baccharis dracunculifolia DC. & Arbu. & $\mathrm{Pi}$ & Anem. \\
\hline & Baccharis trimera (Less.) DC. & Herb. & $\mathrm{Pi}$ & Anem. \\
\hline & Baccharis trinervis Pers. & Arbu. & $\mathrm{Pi}$ & Anem. \\
\hline & Bidens sp. & Herb. & $\mathrm{Pi}$ & Zooc. \\
\hline & Blainvillea biaristata DC. & Herb. & $\mathrm{Pi}$ & Zooc. \\
\hline & Conyza bonariensis (L.) Cronquist & Herb. & $\mathrm{Pi}$ & Anem. \\
\hline & Conyza canadensis (L.) Cronquist & Herb. & $\mathrm{Pi}$ & Anem. \\
\hline & Crepis japonica (L.) Benth. & Herb. & $\mathrm{Pi}$ & Anem. \\
\hline & Emilia fosbergii Nicolson & Herb. & $\mathrm{Pi}$ & Anem. \\
\hline & Erechtites hieraciifolius (L.) Raf. ex DC. & Herb. & $\mathrm{Pi}$ & Zooc. \\
\hline & Eupatorium laevigatum Lam. & Arbu. & $\mathrm{Pi}$ & Anem. \\
\hline & Eupatorium sp. & Arbu. & $\mathrm{Pi}$ & Anem. \\
\hline & Gnaphalium purpureum L. & Herb. & $\mathrm{Pi}$ & Anem. \\
\hline & Gnaphalium spicatum Mill. & Herb. & $\mathrm{Pi}$ & Anem. \\
\hline & Hypochoeris brasiliensis (Less.) Griseb. & Herb. & $\mathrm{Pi}$ & Anem. \\
\hline & Melampodium divaricatum (Rich.) DC. & Herb. & $\mathrm{Pi}$ & SC \\
\hline & Piptocarpha macropoda (DC.) Baker & Arbo. & $\mathrm{Pi}$ & Zooc. \\
\hline & Pluchea sagittalis (Lam.) Cabrera & Herb. & $\mathrm{Pi}$ & Anem. \\
\hline & Siegesbeckia orientalis L. & Herb. & $\mathrm{Pi}$ & Anem. \\
\hline & Sonchus oleraceus L. & Herb. & $\mathrm{Pi}$ & Anem. \\
\hline & Vernonanthura diffusa (Less.) H. Rob. & Arbo. & $\mathrm{Pi}$ & Anem. \\
\hline & Vernonia polyanthes Less. & Arbo. & $\mathrm{Pi}$ & Anem. \\
\hline & Vernonia scorpioides (Lam.) Pers. & Herb. & $\mathrm{Pi}$ & Anem. \\
\hline BRASSICACEAE & Lepidium sp. & Herb. & $\mathrm{Pi}$ & Anem. \\
\hline CANNABACEAE & Trema micrantha (L.) Blume & Arbo. & $\mathrm{Pi}$ & Zooc. \\
\hline COMMELINACEAE & Commelina sp. & Herb. & $\mathrm{Pi}$ & Anem. \\
\hline \multirow[t]{2}{*}{ CYPERACEAE } & Cyperus rotundus $\mathrm{L}$. & Herb. & $\mathrm{Pi}$ & Anem. \\
\hline & Cyperus esculentus L. & Herb. & $\mathrm{Pi}$ & Anem. \\
\hline \multirow[t]{7}{*}{ EUPHORBIACEAE } & $\begin{array}{l}\text { Alchornea triplinervia (Sprengel) } \\
\text { Müller Argoviensis }\end{array}$ & Arbo. & $\mathrm{Pi}$ & Zooc. \\
\hline & Chamaesyce hyssopifolia (L.) Small & Herb. & $\mathrm{Pi}$ & Anem. \\
\hline & Croton floribundus Spreng. & Arbo. & $\mathrm{Pi}$ & Aut. \\
\hline & Croton urucurana Baill. & Arbo. & $\mathrm{Pi}$ & Aut. \\
\hline & Manihot pilosa Pohl & Arbu. & $\mathrm{Pi}$ & Zooc. \\
\hline & Phyllanthus tenellus Roxb. & Herb. & $\mathrm{Pi}$ & Anem. \\
\hline & Sapium glandulatum (Vell.) Pax & Arbo. & $\mathrm{Pi}$ & Zooc. \\
\hline \multirow[t]{5}{*}{ FABACEAE } & Aeschynomene rudis Benth. & Arbu. & $\mathrm{Pi}$ & Anem. \\
\hline & Crotalaria incana $\mathrm{L}$. & Arbu. & $\mathrm{SC}$ & Aut. \\
\hline & $\begin{array}{l}\text { Senna macranthera (DC. ex Collad.) } \\
\text { H.S. Irwin \& Barneby }\end{array}$ & Arbo. & $\mathrm{Pi}$ & Aut. \\
\hline & Senna multijuga (Rich.) H.S. Irwin \& Barneby & Arbo. & $\mathrm{Pi}$ & Aut. \\
\hline & Senna obtusifolia (L.) H.S. Irwin \& Barneby & Arbu. & $\mathrm{Pi}$ & Aut. \\
\hline
\end{tabular}


Table 1...

Tabela 1...

\begin{tabular}{|c|c|c|c|c|}
\hline \multirow[t]{2}{*}{ LAMIACEAE } & Hyptis pectinata (L.) Poit. & Herb. & $\mathrm{Pi}$ & Anem. \\
\hline & Aegiphila sellowiana Cham & Arbo. & $\mathrm{Pi}$ & Zooc. \\
\hline \multirow[t]{7}{*}{ MALVACEAE } & Herissantia tiubae (K. Schum.) Brizicky & Herb. & $\mathrm{Pi}$ & SC \\
\hline & Luehea grandiflora Mart & Arbo. & $\mathrm{Pi}$ & Anem. \\
\hline & Pseudobombax grandiflorum (Cav.) A. Robyns & Arbo. & $\mathrm{Pi}$ & Anem. \\
\hline & Sida rhombifolia $\mathrm{L}$. & Herb. & $\mathrm{Pi}$ & Zooc. \\
\hline & Sida santaremensis Monteiro & Herb. & $\mathrm{Pi}$ & Zooc. \\
\hline & Sida urens L. & Herb. & $\mathrm{Pi}$ & Zooc. \\
\hline & Triumfetta bartramii $\mathrm{L}$ & Arbo. & $\mathrm{Pi}$ & Zooc. \\
\hline \multirow[t]{5}{*}{ MELASTOMATACEAE } & Leandra niangaeformis Cogn. & Arbu. & $\mathrm{Pi}$ & Zooc. \\
\hline & Leandra purpurascens (DC.) Cogn. & Arbu. & $\mathrm{Pi}$ & Zooc. \\
\hline & Leandra sp. & Arbu. & $\mathrm{Pi}$ & Zooc. \\
\hline & Miconia cinnamomifolia (DC.) Naudin & Arbo. & $\mathrm{Pi}$ & Zooc. \\
\hline & Tibouchina granulosa (Desr.) Cogn. & Arbo. & $\mathrm{Pi}$ & Anem. \\
\hline MYRTACEAE & Psidium guajava $\mathrm{L}$. & Arbo. & $\mathrm{Pi}$ & Zooc. \\
\hline \multirow[t]{2}{*}{ MORACEAE } & Ficus guaranitica Chodat & Arbo. & $\mathrm{Si}$ & Zooc. \\
\hline & Ficus sp. & Arbo. & SC & SC \\
\hline MUNTIGIACEAE & Muntingia calabura L. & Arbo. & $\mathrm{Pi}$ & Zooc. \\
\hline \multirow[t]{3}{*}{ PIPERACEAE } & Piper aduncum $\mathrm{L}$. & Arbu. & $\mathrm{Pi}$ & Zooc. \\
\hline & Piper sp. & Arbu. & SC & Zooc. \\
\hline & Pothomorphe umbellata (L.) Miq. & Arbu. & $\mathrm{Pi}$ & Zooc. \\
\hline PLANTAGINACEAE & Scoparia dulcis L. & Herb. & $\mathrm{Pi}$ & Anem. \\
\hline POLYGALACEAE & Polygala paniculata $\mathrm{L}$. & Herb. & $\mathrm{Pi}$ & Anem. \\
\hline PRIMULACEAE & Rapanea ferruginea (Ruiz \& Pav.) Mez & Arbo. & $\mathrm{Pi}$ & Zooc. \\
\hline \multirow[t]{2}{*}{ ROSACEAE } & Rubus brasiliensis Mart. & Arbu. & SC & Zooc. \\
\hline & Rubus rosifolius $\mathrm{Sm}$. & Arbu. & $\mathrm{Pi}$ & Zooc. \\
\hline \multirow[t]{6}{*}{ RUBIACEAE } & Coffea arabica $\mathrm{L}$. & Arbu. & $\mathrm{SC}$ & Zooc. \\
\hline & Diodia teres Walter & Herb. & $\mathrm{Pi}$ & Zooc. \\
\hline & Psychotria sessilis Vell. & Arbo. & $\mathrm{Si}$ & Zooc. \\
\hline & Spermacoce capitata Ruiz \& Pav. & Herb. & $\mathrm{Pi}$ & Zooc. \\
\hline & Spermacoce latifola Aubl. & Herb. & $\mathrm{Pi}$ & Zooc. \\
\hline & Spermacoce verticillata $\mathrm{L}$. & Herb. & $\mathrm{Pi}$ & Zooc. \\
\hline \multirow[t]{3}{*}{ RUTACEAE } & Dictyoloma vandellianum A.H.L. Juss. & Arbo. & $\mathrm{Si}$ & Anem. \\
\hline & Zanthoxylum hasslerianum (Chodat) Pirani & Arbo. & $\mathrm{Pi}$ & Zooc. \\
\hline & Zanthoxylum rhoifolium Lam. & Arbo. & $\mathrm{Pi}$ & Zooc. \\
\hline SAPINDACEAE & $\begin{array}{l}\text { Allophylus edulis (A. St.-Hil., A. Juss. } \\
\text { \& Cambess.) Hieron. ex Niederl. }\end{array}$ & Arbo. & $\mathrm{Si}$ & Zooc. \\
\hline SCROPHULARIACEAE & Buddleja sp. & Herb. & $\mathrm{SC}$ & $\mathrm{SC}$ \\
\hline \multirow[t]{11}{*}{ SOLANACEAE } & Cestrum sp. & Arbo. & $\mathrm{SC}$ & $\mathrm{SC}$ \\
\hline & Nicandra physalodes (L.) Gaertn. & Herb. & $\mathrm{Pi}$ & Aut. \\
\hline & Physalis angulata $\mathrm{L}$. & Herb. & $\mathrm{Pi}$ & Zooc. \\
\hline & Physalis pubescens $\mathrm{L}$. & Herb. & $\mathrm{Pi}$ & Zooc. \\
\hline & Solanum americanum Mill. & Herb. & $\mathrm{Pi}$ & Zooc. \\
\hline & Solanum cernuum Vell. & Arbu. & $\mathrm{Pi}$ & Zooc. \\
\hline & Solanum diflorum Vell. & Arbu. & $\mathrm{Pi}$ & Zooc. \\
\hline & Solanum erianthum D. Don & Arbu. & $\mathrm{Pi}$ & Zooc. \\
\hline & Solanum lycocarpum A. St.-Hil. & Arbu. & $\mathrm{Pi}$ & Zooc. \\
\hline & Solanum paniculatum $\mathrm{L}$. & Arbu. & $\mathrm{Pi}$ & Zooc. \\
\hline & Solanum nigrum L. & Herb. & $\mathrm{Pi}$ & Zooc. \\
\hline \multirow[t]{3}{*}{ URTICACEAE } & Boehmeria nivea (L.) Gaudich. & Arbu. & $\mathrm{Pi}$ & Anem. \\
\hline & Cecropia hololeuca Miq. & Arbo. & $\mathrm{Pi}$ & Zooc. \\
\hline & Phenax sonneratii (Poir.) Wedd. & Herb. & $\mathrm{Pi}$ & SC \\
\hline \multirow[t]{3}{*}{ VERBENACEAE } & Lantana camara $\mathrm{L}$ & Arbu. & $\mathrm{Pi}$ & Zooc. \\
\hline & Stachytarpheta cayennensis (Rich.) Vahl & Herb. & $\mathrm{Pi}$ & Anem. \\
\hline & Stachytarpheta jamaicensis (L.) Vahl & Herb. & $\mathrm{Pi}$ & Anem. \\
\hline
\end{tabular}

Revista Árvore, Viçosa-MG, v.40, n.6, p.991-1001, 2016 
Table 3 - Number of species present in the soil seed bank in areas of forest in advanced regeneration stage (FAS), forest in medium regeneration stage (FMS) and pasture (PAS), according to life form. Number of individuals in parenthesis.

Tabela 3 - Número de espécies presentes no banco de sementes no solo em área de floresta em estádio avançado de regeneração (FEA), floresta em estádio médio (FEM) e pastagem (PAS), de acordo com a forma de vida. Entre parênteses, número de indivíduos.

\begin{tabular}{cccc}
\hline Forma de vida/Ambiente & FEA & FEM & PAS \\
\hline Arbórea & $23(920)$ & $20(5.708)$ & $15(656)$ \\
Arbusto & $17(1.183)$ & $23(7.250)$ & $18(952)$ \\
Herbácea & $31(1.051)$ & $31(2.819)$ & $46(8.170)$ \\
Cipós & $-(236)$ & $-(110)$ & $-(146)$ \\
Gramíneas & $-(75)$ & $-(4.805)$ & $-(1.322)$ \\
Sem caracterização & $01(06)$ & $01(12)$ & $01(56)$ \\
\hline
\end{tabular}

Seasonal variation in fruiting and dispersal of seeds in tropical forests has a great influence on the abundance of seeds in the community, and density over the year will depend on several factors, such as predators, rapid germination or mortality due to fungal and pathogen attack ( DALLING et al., 1998). In a study on seed bank of pioneer species (Miconia and Cecropia) in Panama, Dalling et al. (1998) observed that such genera had a rapid decrease in seed density over the year since the dispersion, reflecting on the variation in their abundance in the presence of a disturbance. GromboneGuaratini and Rodrigues (2002) recorded in fragments of seasonal semideciduous forest, high peaks of seed rain at the end of the dry season and higher density in the seed bank in the soil in the rainy season. Similarly, in EPTEA, fruit dispersion peak is at the end of the dry season, while in the rainy season, it is minimal (PINTO et al., 2008), which explains, in part, the density difference in the seed bank between the two seasons.

The significant heterogeneity of the seed bank composition among the fragments is likely to have been caused by the fact that the areas are in different successional stages, whose factor is related to the variations of the physical environment. Shen et al. (2007) report that local physical conditions may be sufficient to modify the seasonal pattern of seed bank composition, since some species have seeds with characteristics that do not allow them to remain in the seed bank for a long time. Furthermore, such composition may also be influenced by the neighboring community, since the arrival of diaspores by means of seed rain is not exclusive to the species belonging to the community itself (GROMBONE-GUARATINI; RODRIGUES, 2002; CAMPOS et al., 2009).

The environmental disturbance record also has its contribution to the composition of the seed bank
(LUZURIAGA et al., 2005), where areas with secondary vegetation that have already been used for agricultural activities may have a seed bank formed mainly by grasses or ruderal herbaceous species, which remain there for several years. This explains the high abundance of these life forms in the intermediate regeneration stage forest, which was pasture until 1963 , besides being surrounded by other pasture areas. Several studies have shown that more open or at initial stage of succession environments exhibit high species richness, being associated mainly with the presence of herbaceous plants (BAIDER et al., 2001; MARTINS; ENGEL, 2007; VINHA et al., 2011) whereas little disturbed areas present seed banks with less richness (LINDNER, 2009).

In this sense, although the intermediate stage forest had shown significant differences in the average seed bank richness in relation to the stretch in the regeneration advance stage forest and pasture, the greatest richness found in this last environment is explained by the high occurrence of herbaceous species (Table 3 ), a characteristic of open areas or areas close to them. Pasture seed bank is composed of almost $60 \%$ of herbaceous species (Table 3 ), which are mostly ruderal plants, such as Bidens sp., Crepis japonica, Emilia fosbergii, Erechtites hieraciifolius and those of Gnaphalium and Sida genera.

In proportional terms of the number of germinated seeds, herbaceous species (grasses and herbs) are replaced by woody species in the forest fragments, mainly shrubs (Figure 1A), but there is still a large incidence of grasses in the intermediate stage forest seed bank ( Figure 1B), a likely reflection of the use record of the area. In addition, grass and herbaceous species are dominant in spots with higher light intensity in the ISF (personal observation). Similarly, in relation to the number of species, the seed bank is composed 
of more woody species in forest fragments, with similar proportions between shrubs and trees (Figure 1C, 1D).

Grombone-Guaratini and Rodrigues (2002) and Vinha et al. (2011) found similarities in the richness of herbaceous and arboreal species for undisturbed areas, but the abundance of trees was much higher. In the present study, although herbaceous plants had predominated in richness, seed abundance of shrub-tree species is much higher than herbaceous species in mature and early forest stretches (Table 3, Figure 1A), which can be partly explained by the existence of a forest community already established in these environments.

The absence of late species in the seed bank in the soil may have been caused by two factors: a) species of more advanced succession stages produce large seeds and in smaller quantity (WHITMORE, 1989). In fact, seeds larger than $5 \mathrm{~mm}$ are more difficult to be incorporated into the soil (FOSTER, 1986), and because of that they may remain only on the surface where they are subject to attack by predators and pathogens (BAIDER et al., 1999); B) these species present facultative dormancy and can germinate rapidly, constituting the seedlings bank, or remain dormant under adverse physical conditions.

All the stretches presented a greater number of zoocoric species, corresponding to $40 \%-45 \%$ in each fragment. Although it has stood out, this syndrome is expressed in higher percentages (50-90\%) in tropical forests (HOWE; SMALLWOOD, 1982). In Brazilian rainy forests, the occurrence of zoocory may exceed $80 \%$ (MORELLATO; LEITÃO FILHO, 1992), but this proportion decreases from humid areas towards dry areas (GENTRY, 1982).

The seasonal semideciduous forest $(60 \%)$, due to its foliar caducity $(60 \%)$ during the dry season
A.

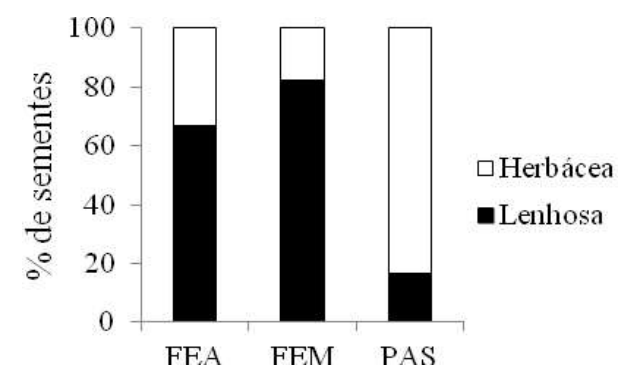

C.

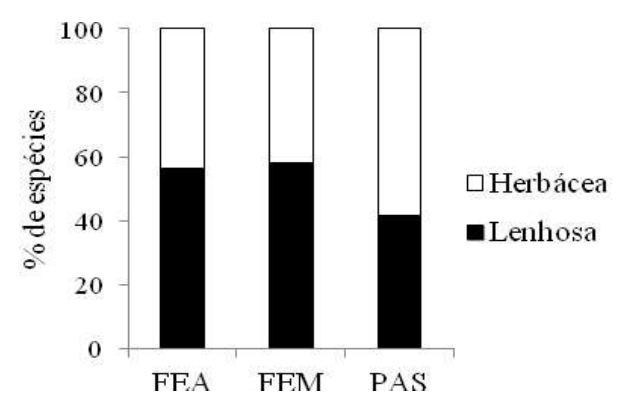

B.

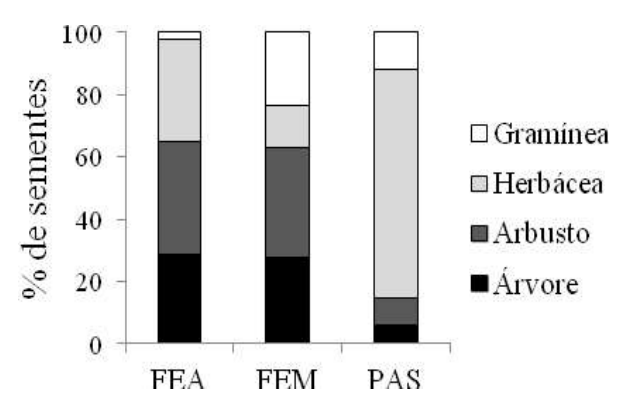

D.

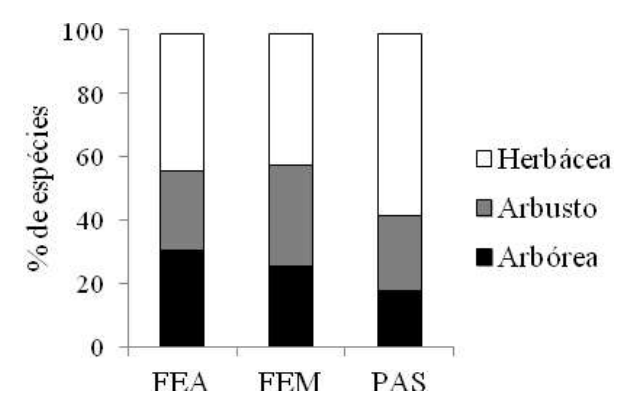

Figure 1 - Relative contribution of the number of seeds and species of different life forms in the soil seed bank sampled in forest in advanced regeneration stage (FEA), forest in medium regeneration stage (FEM) and abandoned pasture (PAS).

Figura 1 - Contribuição relativa do número de sementes e espécies de diferentes formas de vida no banco de sementes no solo amostrado na floresta em estádio avançado (FEA), floresta em estádio médio (FEM) e pastagem abandonada (PAS).

Revista Árvore, Viçosa-MG, v.40, n.6, p.991-1001, 2016 
(MORELLATO, 1995) allows a greater flow of wind in the ecosystem. This characteristic in the area of the present study may have contributed to the large amount of anemochloric seeds (32.7\%) deposited inside the forest areas, among which the herbaceous ( 23 species) stands out.

The most abundant tree species that occurred in all environments in the two seasons were Vernonanthura diffusa (2,968 germinant individuals), Miconia cinnamomifolia (1,003), Trema micrantha (856) and Cecropia hololeuca (584). However, $V$. diffuse was practically only found in the intermediate regeneration stage forest stretch. The most abundant shrubs were Leandra niangaeformis (4405) and Leandra purpurascens (1,569 germinating individuals).

The high representativeness of these species in this study is a striking feature in seed banks in the soil of seasonal semideciduous forests (BATISTANETO et al., 2007; MARTINS and ENGEL, 2007; BRAGA et al., 2008, CAMARGOS et al., 2013) and dominance by a few abundant species is common, as reported by Lindner (2009), in ombrophylous forest and by Scherer and Jarenkow (2006), in seasonal forest, both of Atlantic Forest.

Leandra, Miconia, Cecropia and T. micrantha produce small, high longevity seeds that are dispersed by generalist birds and because of that have a large stock of seeds in the soil over extensive areas (STILES and ROSSELLI, 1993). The family Melastomataceae, represented in this paper by the genera Leandra, Miconia and Tibouchina, is recognized as one of the most important families in the colonization of disturbed environments in the Atlantic Forest (BAIDER et al., 1999; VINHA et al., 2011) such as edge of forests or large clearings, which characterize them as pioneer.

\section{CONCLUSION}

The seed bank in the soil presented spatial and seasonal variations only in relation to the abundance of seeds, since the richness of species was not influenced by the weather seasonality. A higher resilience potential may be attributed to the forest at an advanced stage of regeneration, where the seed bank consists of seeds of different life forms, mainly by early and late secondary species. The other fragments (FEM and PAS) also present favorable natural regeneration conditions, since the seeds present in the soil are of arboreal, shrub and herbaceous species. However, the abundance of herbaceous seeds and aggressive grasses and the absence of late secondary species, along with the low representativeness of early secondary ones indicate a certain fragility of the seed bank of these fragments towards some more severe disturbance event, as well as they may delay the process of forest succession.

The presence of tree species and pioneer shrubs in the pasture seed bank shows that although there is potential for secondary succession in this area, this process has been inhibited by the aggressive cover of the soil exerted by Melinis minutiflora, which hinders seed germination and establishment of native species seedlings.

\section{ACKNOWLEDGEMENT}

The authors thank CNPq for their financial support in the development of this study (Universal Public Notice-MCT/CNPq 15/2007), for granting the scholarship for higher technical support, for doctoral studies to the first author and for research productivity to the second author. To the Federal University of Viçosa and to the Federal University of Espírito Santo for their support.

\section{REFERENCES}

APG III. An update of the Angiosperm Phylogeny Group classiûcation for the orders and families of ûowering plants: APG III. Botanical Journal of the Linnean Society, n.161, p.105-121, 2009.

ARAUJO, M.M.; OLIVEIRA, F.A.; VIEIRA, I.C.G.; BARROS, P.L.C.; LIMA, C.A.T. Densidade e composição florística do banco de sementes do solo de florestas sucessionais na região do Baixo Rio Guamá, Amazônia Oriental. Scientia Forestalis, v.59, p.15-130, 2001

BAIDER, C.; TABARELLI, M.; MANTOVANI, W. O banco de sementes de um trecho de floresta Atlântica montana (São Paulo, Brasil). Revista Brasileira de Biologia, v.59, n.2, p.319-328, 1999.

BAIDER, C.; TABARELLI, M.; MANTOVANI, W. The soil seed bank during Atlantic forest regeneration in southeast Brazil. Revista Brasileira de Biologia, v.61, n.1, p.35-44, 2001.

Revista Árvore, Viçosa-MG, v.40, n.6, p.991-1001, 2016

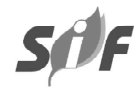


BARUQUI, F.M.; RESENDE, M.; FIGUEIREDO, M.S. Causas da degradação e possibilidades de recuperação das pastagens em Minas Gerais (Zona da Mata e Rio Doce). Informe Agropecuário, v.11, p.27-37, 1985.

BATISTA NETO, J.P.; REIS, M.G.F.; REIS, G.G.; SILVA, A.F.; CACAU, F.V. Banco de sementes do solo de uma Floresta Estacional Semidecidual, em Viçosa, Minas Gerais. Ciência Florestal, v.17, n.4, p.311-320, 2007.

BRAGA, A.G.T.; GRIFFITH, J.J.; PAIVA, H.N.; MEIRA NETO, J.A.A. Composição do banco de sementes de uma floresta semidecidual secundária considerando o seu potencial de uso para recuperação ambiental. Revista Árvore, v.32, n.6, p.1089-1098, 2008.

BROWN, D. Estimating the composition of a forest seed bank: a comparison of the seed extraction and seedling emergence methods. Canadian Journal of Botany, v. 70, n.8, p.1603-1612, 1992.

BUTLER, B.J.; CHAZDON, R.L. Species richness, spatial variation, and abundance of the soil seed bank of a secondary tropical rain forest.

Biotropica, v.30, n.2, p.214-222, 1998.

CAMARGOS, V.L.; MARTINS, S.V.; RIBEIRO, G.A.; SILVA, F.M.C.; SILVA, A.F. Influência do fogo no banco de sementes do solo em Floresta Estacional Semidecidual. Ciência Florestal, v.23, n.1, p.19-28, 2013.

CAMPOS, É.P.; VIEIRA, M.F.; SILVA, A.F.; MARTINS, S.V.; CARMO, F.M.S.; MOURA, V.M.; RIBEIRO, A.S.S. Chuva de sementes em Floresta Estacional Semidecidual em Viçosa, MG, Brasil.

Acta Botanica Brasilica, v.23, n.2, p.451$458,2009$.

CASTRO, P.S.; VALENTE, F.; COELHO, D.T.; RAMALHO, R.S. Interceptação da chuva por mata natural secundária na região de Viçosa - MG. Revista Árvore, v.7, n.1, p.76-89, 1983.

COSTALONGA, S.R.; REIS, G.G.; REIS, M.G.F.; SILVA, A.F.; LIMA E BORGES, E.E.; GUIMARÃES, F.P. Florística do banco de sementes do solo em áreas contíguas de pastagem degradada, plantio de eucalipto e floresta em Paula Cândido, MG. Floresta, v.36, n.2, p.239-250, 2006.

DALLING, J.W.; SWAINE, M.D.; GARWOOD, N.C. Dispersal patterns and seed bank dynamics of pioneer trees in moist tropical forest. Ecology, v.79, n.2, p.564-578, 1998.

FOSTER, S.A. On adaptative value of large seeds for tropical moist forest trees: a review and synthesis. The Botanical Review, v.52, n.3, p.260-269, 1986.

GENTRY, A.H. Patterns of neotropical plant species diversity. Evolutionary Biology, v.15, p.1-84, 1982.

GROMBONE-GUARATINI, M.T.; RODRIGUES, R.R. Seed bank and seed rain in a seasonal semideciduous forest in south-eastern Brazil.

Journal of Tropical Ecology, v. 18, n.5, p.759-774, 2002.

HORN, H.S. The ecology of secondary succession. Annual Review of Ecology and Systematics, v.5, p.25-37, 1974.

HOWE, H.F.; SMALLWOOD, J. Ecology of seed dispersal. Annual Review of Ecology and Systematics, v.13, p.201-228, 1982.

INSTITUTO BRASILEIRO DE GEOGRAFIA E ESTATÍSTICA - IBGE. Manual técnico da vegetação brasileira. 2. ed. Rio de Janeiro: IBGE, 2012.271p.

KÖPPEN, W. Climatologia: con um estúdio de los climas de la Tierra. México: Fondo de Cultura Economica, 1948. 478p.

LINDNER, A. A rapid assessment approach on soil seed banks of Atlantic forest sites with different disturbance history in Rio de Janeiro, Brazil. Ecological Engineering, v.35, n.5, p.829-835, 2009.

LUZURIAGA, Q.L.; ESCUDERO, A.; OLANO, J.M.; LOIDI, J. Regenerative role of seed banks following na intense soil disturbance. Acta Oecologica, v.27, n.1, p.57-66, 2005.

MARTINS, A.M.; ENGEL, V.L. Soil seed banks in tropical forest fragments with different 
disturbance histories in southeastern Brazil. Ecological Engineering, v. 31, n.3, p.165174, 2007.

MORELLATO, L.P.C.; LEITÃO-FILHO, H.F. Padrões de frutificação e dispersão na serra do Japi. In: MORELLATO, L.P.C. (Org.). História natural da serra do Japi: ecologia e preservação de uma área florestal no sudeste do Brasil. Campinas: UNICAMP, 1992. p.112-140.

MORELLATO, L.P.C. As estações do ano na floresta. In: LEITÃO-FILHO, H.F.; MORELLATO, L.P.C. (Ed.). Ecologia e preservação de uma floresta tropical urbana: reserva de Santa Genebra. Campinas: UNICAMP, 1995. p.37-41.

PINTO, I.C.P.; MARTINS, S.V.; BARROS, N.F.; DIAS, H.C.T. Produção de serapilheira em dois estádios sucessionais de Floresta Estacional Semidecidual na Reserva Mata do Paraíso, em Viçosa, MG. Revista Árvore, v.32, n.3, p.545$556,2008$.

R DEVELOPMENT CORE TEAM. R: a language and environment for statistical computing. Austria: R Foundation for Statistical Computing, 2014.

SCHERER, C.; JARENKOW, J.A. Banco de sementes de espécies arbóreas em floresta estacional no Rio Grande do Sul, Brasil. Revista Brasileira de Botânica, v.29, n.1, p.67-77, 2006.
SHEN, Y.; LIU, W; CAO, M.; LI, Y. Seasonal variation in density and species richness of soil seed-banks in karst forests and degraded vegetation in central Yunnan, SW China. Seed Science Research, v.17, n.2, p.99-107, 2007.

SOUZA, P.A.; VENTURIN, N.; GRIFFITH, J.J.; MARTINS, S.V. Avaliação do banco de sementes contido na serapilheira de um fragmento florestal visando recuperação de áreas degradadas.

Cerne, v.12, n.1, p.56-67, 2006.

STILES, F.G.; ROSSELLI, L. Consumption of fruits of the Melastomataceae: how diffuse is coevolution. Vegetatio, v.107/108, n.1, p.57-73, 1993.

VINHA, D.; ALVES, L.F.; ZAIDAN, L.B.P.; GROMBONE-GUARATINI, M.T. The potential of the soil seed bank for the regeneration of a tropical urban forest dominated by bamboo. Landscape and Urban Planning, v.99, n.2, p.178-185, 2011 .

WALCK, J.L.; BASKIN, J.M.; BASKIN, C.C.; HIDAYATI, S.N. Defining transient and persistent seed banks in species with pronounced seasonal dormancy and germination patterns. Seed Science Research, v. 15, n.3, p.189-196, 2005.

WHITMORE, T.C. Canopy gaps and the two major groups of forest trees. Ecology, v.70, n.3, p.536$538,1989$. 